\title{
Information technologies as applied to translation of specialized texts
}

\author{
A. Dolzhikova \\ RUDN University \\ Moscow, Russia \\ authorsrudn@gmail.com
}

Yu. Biryukova

Russian language department

RUDN University

Moscow, Russia

yu.birukova@gmail.com

\author{
V. Kurilenko \\ head of Russian language department \\ RUDN University \\ Moscow Russia \\ vbkurilenko@gmail.com
}

\author{
K. Akhnina \\ Russian language department \\ RUDN University \\ Moscow, Russia \\ akhninakristine@gmail.com
}

\author{
E. Kulikova \\ Migration Centre \\ RUDN University \\ Moscow, Russia \\ pfurteachers@gmail.com
}

\begin{abstract}
The purpose of this article is to find out information technologies used by translators in their professional activity. For this purpose, the concept of "information translation environment" was analyzed, including information technologies used by professional translators. Researchers distinguish various types of information technologies which can be used by translators. In order to systematize them, an analysis of the studies and survey of professional translators were carried out. The analysis of studies made it possible to define three groups of information resources: the information resources used in the translation process; network information technologies; and auxiliary information resources. As an example, the group of information resources used in the translation process was analyzed, and difficulties encountered by translators in their work were highlighted. The results obtained from the studies and survey of translators can be used for preparing lectures on translation didactics and developing practical materials on forming technical translators' information competency.
\end{abstract}

Keywords-information translation environment, information resources used by translators, network information technologies, auxiliary information resources.

\section{INTRODUCTION}

At the present stage of technological development, information technologies (IT) have become the main tool in any human activities; this affects both IT specialists and people who are not specially trained in these technologies but needing them to optimize their work.
The introduction of IT, automation, and computerization of the professional activities of translators have changed the traditional concept of their professionalism. Today, professional translators should not only be proficient in their native and foreign languages, trained in the translation fundamentals and experienced in specific subject areas but also be able to use ITs as tools allowing them to significantly reduce the time required for searching for dictionaries, translation equivalents and correspondences or formatting the target text depending on the customer's requirements.

IT proficiency takes on special significance in scientific and technical translations, since it allows translators to use a personal computer not only as a typewriter with minimal text editing elements but to make the most use of all its capabilities, including all useful additional functions and programs. The need to consider the problems of teaching translation of scientific and technical texts using IT is defined by a new social order for training highly professional translators.

\section{TRANSLATION INFORMATION ENVIRONMENT}

Translation of scientific and technical texts, being an independent professional activity, is performed in a certain professional environment. Researchers note that the professional environment is nonhomogeneous. It comprises the subject subsystem including the subject itself, means and tools, and the social subsystem including human relationships, climate in labor, subjective perception and awareness by participants themselves of different aspects of labor [1: 105]. 
The translation professional environment includes the conditions in which professional translation activities are performed, the tasks facing the translator, and the means used to achieve the objectives.

Due to the fact that the professional environment can change under the influence of technological, economic and organizational factors, in the era of informatization, it is possible to identify the information environment within its framework.

The concept of "information environment" was first proposed by Yu.A. Shreder, who viewed it not only as a conductor of information but also as an active principle affecting its participants. In accordance with the Concept of Informatization of the Education Sector of the Russian Federation, an "information environment" is understood as a set of software and hardware, information communication networks, organizational and methodological elements of a higher school system and applied information about the subject area recognized and applied by various users, possibly with different goals and in different senses.

Researchers consider: the "integrated information environment", "information-objective environment", "scientific-information environment", and "informationeducational environment".

Considering the information environment in the translators' activity, researchers have in mind hardware and software as well as electronic resources, and define it as a unified translation service complex, which is a translator's "electronic workplace" [2: 232-233]. Today, the activity of translators of scientific and technical texts is related to the production, storage, exchange, retrieval and use of various data, and most of these translation activities are mediated by ITs. To meet modern requirements for translation quality and efficiency, many translators use an automated translator workplace (ATWP), which is a combination of technical and software tools designed to ensure the translator-computer interaction, automate professional activities, and provide translators with ITs targeted at specific professional tasks [3: 86]. Therefore, ITs used by translators for solving their problems represent the subject subsystem and are an integral component of the professional environment.

However, according to A.K. Markova, a component of the professional environment is also the social subsystem [1]. In the authors' opinion, this subsystem as part of the translation information environment assumes the translator's communication with ITs and computer equipment (for carrying out reference and information search and translation analysis of the text, selecting translation correspondences and equivalents, etc.) as well as IT-mediated communication with the employer, colleagues, consultants, and specialists in the professional sphere.

The foregoing allows us to assume that, in addition to ITs, computer-mediated communication becomes an integral part of the information translation environment, which presupposes the presence of the "Human-Information Technologies" relations.
Thus, the information translation environment is a set of computer-mediated communication and information technologies in the form of software and hardware storage, processing, information transfer used by translators for solving their tasks.

It should be noted that researches distinguish separate IT types which can be used by translators $[3,4,5,6,7,8,9]$. The need to provide an aggregate picture of ITs used by translators has led to their analysis within the information translation environment, of which they are an integral component.

\section{INFORMATIONAL TECHNOLOGIES USED BY TRANSLATORS OF SCIENTIFIC AND TECHNICAL TEXTS}

To describe modern computer technologies, researchers use the following terms: "new information technologies", "information technologies", "information and communication technologies", and "computer technologies" [10, 3]. The authors' analysis showed that, in general, researchers put approximately the same meaning in these concepts and consider them as the technology of accumulation, storage, transmission, processing, and control of information based on the use of hardware and software and communication means.

Based on the definitions of I.G. Zakharova and A.L. Semenov, let us assume that ITs in the translators' activity imply the use of a computer as a means of implementing software for creating, collecting, transmitting, storing and processing information in translations of scientific and technical texts $[11,12]$.

To determine the types of IT used by translators in their activities, the authors analyzed the studies on the means of translation automation and support that appeared due to the computer capabilities, programs for training translators in various higher schools, works of practicing translators, and results of various seminars devoted to translation activities.

The analysis showed that the translator uses text and graphic editors, converters, various spelling checkers, optical text recognition systems, archiving and screenshot creating tools, offline browsers, programs for computer reading, automatic text analysis tools, electronic dictionaries, glossaries, reference books, localization tools, search engines, electronic catalogs, libraries and journals, industry-specific websites and portals, legal reference systems, e-mail, teleconferences, forums, chats, concordancers, and Translation Memory programs.

\section{METHODOLOGY}

To systematize all the above-mentioned information technologies used by translators of scientific and technical texts, a survey of 80 professional translators was conducted. They were asked to answer the following questions: 


\section{TABLE .I QUESTIONNAIRE SAMPLE}

\begin{tabular}{|c|l|l|l|l|}
\hline No. & \multicolumn{1}{|c|}{ Question } & Frequently & Rarely & Never \\
\hline I & $\begin{array}{l}\text { Do you use ITs in } \\
\text { your professional } \\
\text { activity? }\end{array}$ & & & \\
\hline II & $\begin{array}{l}\text { Do you use in your } \\
\text { everyday practice: }\end{array}$ & & & \\
\hline 1 & text editor & & & \\
\hline 2 & graphic editor & & & \\
\hline III & $\begin{array}{l}\text { Distribute the above- } \\
\text { mentioned ITs into } \\
\text { the proposed } \\
\text { categories }\end{array}$ & $\begin{array}{l}\text { programs } \\
\text { used } \\
\text { in the } \\
\text { translation } \\
\text { process }\end{array}$ & $\begin{array}{l}\text { network } \\
\text { information } \\
\text { technologie } \\
\text { s }\end{array}$ & $\begin{array}{l}\text { auxiliary } \\
\text { programs }\end{array}$ \\
\cline { 3 - 5 } IV & $\begin{array}{l}\text { What other } \\
\text { information } \\
\text { technologies do you } \\
\text { use when translating } \\
\text { scientific and } \\
\text { technical texts? }\end{array}$ & \multicolumn{2}{|l}{} & \\
\hline
\end{tabular}

The results of the survey made it possible to distinguish three groups of information resources used by translators for downloading, reading or looking through data:

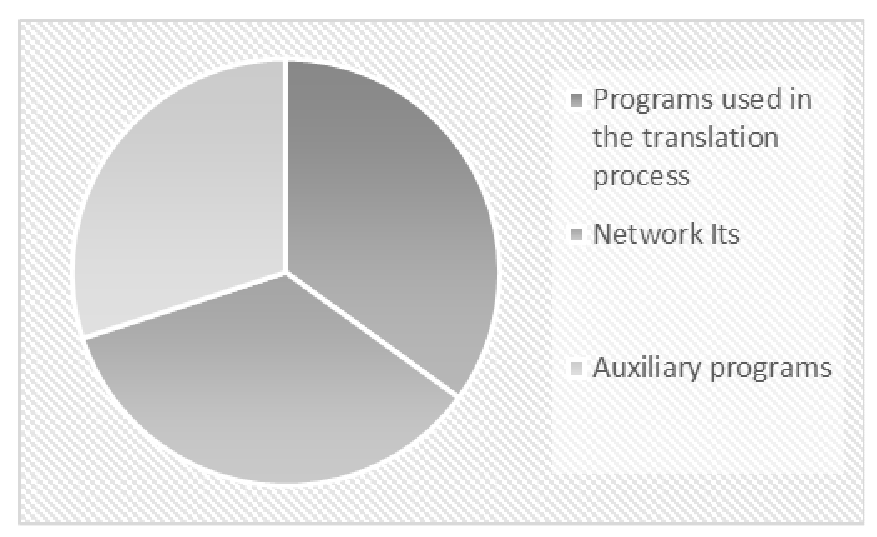

Fig. 1. Translator's informational technologies

The programs used in the translation process include Translation Memory software, electronic dictionaries, encyclopedias and reference books, terminology databases, etc. The network information technologies representing the Internet resources used by translators include search engines, electronic libraries and journals, translation sites and portals, e-mail, newsletters, forums, chats, etc. The auxiliary programs that help translators carry out text formatting include text and graphic editors, converters, etc.

As an example, let us consider the first group of information resources: programs used in the translation process and difficulties that they may present for translators of scientific and technical texts.

\section{Programs used in the translation process}

During the translation process, translators actively use programs based on the Translation Memory technology.

This technology is a specialized database containing in its memory individual words, terms, sentences, paragraphs and variants of correspondences found when translating previous texts and recorded in the translation memory program. If the source text contains words, terms, sentences or paragraphs that partially or completely coincide with the information available in the database, the translator is asked to choose the appropriate translation or make necessary changes to it. Visually, the Translation Memory program has two parallel windows: for the source text and the target translation, respectively.

The Translation Memory program can be located on a network drive, several users can work simultaneously, and the results of the work can be accessed by all translators working for the company/enterprise. The use of drives allows them not to translate text segments that are already contained in the database, avoid repetitive monotonous operations, reduce the time required for translation and improve the productivity of translation work.

At the moment, there are a number of programs that use the Translation Memory technology, for example: $\mathrm{Dj} \mathrm{Vu}$, Trados, Transit, Catalist, Translation Manager and some others. These programs have a number of common functionalities underlined by translation theorists:

- Built-in text editor used for editing the proposed database options and creating texts in the target language. It shows the percentage of coincidence between the currently translated source text and the text contained in the translator's database;

- Electronic interlingual dictionaries and glossaries that can import files in the format of dictionaries and glossaries; they can be replenished using the Internet or manually. Recently, within the framework of the Translation Memory tools, terminology bases have been formed, which are provided by the customer to the translator in order to unify the company's documentation and improve the translation quality;

- Localization of the target text is a special technological operation consisting in the adaptation of the source text according to the peculiarities of the target language: for example, changing the units of measurement, date and time format, etc. This tool in the program allows this information to be reduced in one place so that the translator can have it at hand and perform the translation without errors. Due to the localization tool, Translation Memory eliminates the need to search for these text inclusions, and all the necessary to be taken into account in the translation process is located in one place. The program also offers options for translating segments to be localized: the translator either accepts them or chooses among the variants and prints the suitable one that is stored in the database $[14,15]$;

- Concordance is a useful function of all the Translation Memory programs, which is able to automatically select a word or term and build a list of possible contexts, regardless of their grammatical form, relative position and the number of intermediate words separating them in the sentence. This function allows the translator to read in the window the translations available in the database and facilitates the choice among the translations of a term or phrase $[12,3,9,13,5]$.

When reading texts processed by the Translation Memory program, the translator may have difficulties in perceiving information because the program is highly loaded with various built-in tools. The toolkit is regularly updated, and additional 
functions appear. A translator, who does not know all the program options, may have difficulties in perceiving and understanding information due to the program structure, which will complicate the further translation.

\section{CONCLUSIONS}

Today, translators work in an information translation environment, which implies the active use of information resources in the translation process. IT proficiency allows translators to significantly reduce the time for searching for dictionaries, translation equivalents and correspondences or formating the target text depending on the customer's requirements.

Researchers distinguish various types of information technologies, which can be used by translators. In order to systematize them, an analysis of the studies and survey of professional translators were carried out.

The analysis of studies made it possible to define three groups of information resources used by translators for solving their professional tasks:

- information resources used translation used in the translation process;

- network information technologies;

- auxiliary information resources.

The results obtained from the studies and survey of translators can be used for preparing lectures on translation didactics and developing practical materials on forming technical translators' information competency.

\section{References}

[1] A.K. Markova, Psychology of professionalism, Moscow: Znanie Publ., 1996, $308 \mathrm{p}$.

[2] N.G.Inyutin, Forming the information and technological competence of the future "translator in the sphere of professional communication": Cand. Sci. (Pedagogics) thesis, Novgorod, 2006, 320 p.
[3] A.L. Semenov, Modern information technologies and translation: Textbook for students of translation faculties of higher educational institutions, Moscow: Akademia Publ., 2008, 224 p.

[4] M.A. Zhomin, "Modern translation technologies: from handicraft business to flow production". [Electronic resource]. URL: http://www.logrus.ru/publications/ru-publications/9.aspx

[5] C.K. Quah, Translation and technology: Textbook for students of higher educational institutions. Transl. from Eng. and ed. by A.L. Semenov. Moscow: Akademia Publ., 2008, 256 p.

[6] B.N. Klimzo, "Technical translator's reference database," Mosty (journal for translators and interpreters), No. 2(10), pp. 45-53, 2006.

[7] L.M. Kudryashova, Information problems of scientific and technical translation, Scientific and technical translation. Ed. Prof. Yu.N. Marchuk (DLitt). Moscow: Nauka Publ., 1987, pp. 55-79.

[8] S.F. Rybkin, "Translator's notes, or Man is not against the computer," Computerra, No. 18, 2006. [Electronic resource] URL: http://www.fonetix.ru/articles php?num0=0017.

[9] V.N. Shevchuk, Translator's electronic resources. Moscow: Libright Publ., 2009, 136 p.

[10] A.D. Gartsov, New information technologies in higher education. Information technologies in the methodology of teaching languages: new priorities: lecture course, Moscow: PFUR Publ., 2004, 196 p.

[11] I.G. Zakharova, Information technologies in education: Textbook for students of higher educational institutions. Moscow: Akademia Publ., $2007,192 \mathrm{p}$.

[12] E. Malushko, A. Novozhilova, Ye. Shovgenina, S. Korolkova, A. Shovgenin, "Developing professional competence of a translator: information retrieval and information technology constituents," "3rd international multidisciplinary scientific conference on social sciences \& arts SGEM 2016: conference proceedings," Book 1, vol. 1, pp. 669-676, 2016.

[13] M. Prior, Translation Memory Training Course (2006). [Electronic resource]. URL: http://www.omegat.org/training/documentation/translation memory training course.zip

[14] A. Pym, Website localization. January 28, 2010. [Electronic resource]. URL:

http://usuaris.tinet.cat/apym/online/translation/2009 website localization.pdf

[15]M.A. Suzdalova, V.G. Lizunkov, E.Yu. Malushko, N.A. Sytina, V.E. Med vedev, "Innovative Forms of Partnership in Development and Implementation of University-Business Cooperation," "The European Proceedings of Social \& Behavioural Sciences EpSBS," vol. XIX, Article \#61, pp. 450-455, 2017. 